\title{
Natalizumab-PML survivors with subsequent MS treatment
}

\section{Clinico-radiologic outcome}

\section{OPEN}

Elisabeth Maillart, MD

Jean-Sebastien Vidal,

$\mathrm{MD}, \mathrm{PhD}$

David Brassat, MD, PhD

Bruno Stankoff, MD,

$\mathrm{PhD}$

Agnès Fromont, MD,

$\mathrm{PhD}$

Jérôme de Sèze, MD,

$\mathrm{PhD}$

Frédéric Taithe, MD,

$\mathrm{PhD}$

Pierre Clavelou, MD,

$\mathrm{PhD}$

Bertrand Bourre, MD

Valérie Delvaux, MD,

$\mathrm{PhD}$

Audrey Rico, MD, PhD

Pierre Labauge, MD, PhD

Ayman Tourbah, MD,

$\mathrm{PhD}$

Christine Lebrun, MD,

$\mathrm{PhD}$

Jean Pelletier, MD, PhD

Thibault Moreau, MD,

$\mathrm{PhD}$

Céline Louapre, MD, $\mathrm{PhD}$

Catherine Lubetzki, MD, $\mathrm{PhD}$

Caroline Papeix, MD

On behalf of SFSEP

Correspondence to

Dr. Maillart:

elisabeth.maillart@aphp.fr

\section{Supplemental data} at Neurology.org/nn

\section{ABSTRACT}

Objective: To describe the clinico-radiologic outcome of MS patients with natalizumab-related progressive multifocal leukoencephalopathy (Nz-PML) surviving and receiving diseasemodifying therapy (DMT).

Methods: We describe clinical and radiologic evolution of Nz-PML survivors in an observational retrospective multicenter cohort to clarify the effect of different subsequent MS DMT strategies. Twenty-three patients from 11 centers were analyzed. Outcomes were (1) clinical efficacy of post-PML MS DMT, (2) radiologic efficacy of post-PML MS DMT, (3) radiologic evolution of PML lesion, and (4) disability progression.

Results: There was no clinical worsening of PML symptoms with a stability of Expanded Disability Status Scale at the last follow-up. No relapse was reported with fingolimod and dimethyl fumarate. No radiologic worsening of Nz-PML lesion was observed at the end of the follow-up.

Conclusion: In this large cohort of patients with Nz-PML, MS therapies given after Nz discontinuation were not associated with PML worsening. A larger cohort with longer follow-up will be necessary to confirm this therapeutic strategy. Neurol Neuroimmunol Neuroinflamm 2017;4:e346; doi: $10.1212 / \mathrm{NXI} .0000000000000346$

\section{GLOSSARY}

ARR = annual relapse rate; DMF = dimethyl fumarate; $\mathbf{D M T}=$ disease-modifying treatment; EDMUS = European Database for Multiple Sclerosis; IRIS = immune reconstitution inflammatory syndrome; Nz-PML = natalizumab-related progressive multifocal leukoencephalopathy; PML = progressive multifocal leukoencephalopathy; RR-MS = relapsing-remitting MS.

Natalizumab $(\mathrm{Nz})$ is a disease-modifying therapy (DMT) used to prevent relapses in patients with active relapsing-remitting MS (RR-MS). Progressive multifocal leukoencephalopathy (PML) has been reported as a serious adverse event affecting 1/1,000 to $1 / 100 \mathrm{Nz}$-treated patients ${ }^{1}$ with $20 \%$ of fatal issue. ${ }^{2}$ However, because patients treated with $\mathrm{Nz}$ usually experience an active form of MS, a subsequent treatment is often required after $\mathrm{Nz}$ discontinuation. This post$\mathrm{Nz}$ strategy is challenging for $80 \%$ surviving patients because of the current lack of consensus on post-PML MS treatment strategy. In addition, rare cases of PML have been observed with dimethyl fumarate $(\mathrm{DMF})^{3,4}$ and fingolimod $(\mathrm{Fg}){ }^{5}$ Few cases treated with Fg after Nz-PML have been recently reported without Nz-PML worsening. ${ }^{6}$ Of interest, a similar stability was reported with low dose of rituximab, with a documented follow-up period of 9 months. ${ }^{7}$ We report an observational multicenter retrospective cohort of 23 patients with MS surviving after Nz-PML.

From the Department of Neurology (E.M., C. Louapre, C. Lubetzki, C.P.), Pitié-Salpêtrière Hospital, APHP, Paris; Department of Gerontology (J.-S.V.), Broca Hospital, APHP, Paris; Department of Neurology (D.B.), University Hospital of Toulouse; Department of Neurology (B.S.), SaintAntoine Hospital, APHP, Paris; Department of Neurology (A.F., T.M.), University Hospital of Dijon; Department of Neurology (J.d.S.),

University Hospital of Strasbourg; Department of Neurology (F.T., P.C.), University Hospital of Clermont-Ferrand; Department of Neurology (B.B.), University Hospital of Rouen, France; Department of Neurology (V.D.), University Hospital of Liège, Belgium; APHM (A.R., J.P.), Hôpital de la Timone, Pôle de Neurosciences Cliniques, Service de Neurologie, Marseille; Department of Neurology (P.L.), University Hospital of Montpellier; Department of Neurology (A.T.), University Hospital of Reims, URCA Reims, and LPN EA 2027 University Paris 8, Saint-Denis; and Department of Neurology (C. Lebrun), University Hospital of Nice, France.

SFSEP contributors are listed at Neurology.org/nn.

Funding information and disclosures are provided at the end of the editorial. Go to Neurology.org/nn for full disclosure forms. The Article Processing Charge was funded by the authors.

This is an open access article distributed under the terms of the Creative Commons Attribution-NonCommercial-NoDerivatives License 4.0 (CC BY-NC-ND), which permits downloading and sharing the work provided it is properly cited. The work cannot be changed in any way or used commercially without permission from the journal. 


\begin{tabular}{|c|c|c|}
\hline Table 1 & \multicolumn{2}{|c|}{$\begin{array}{l}\text { General characteristics of patients with } \\
M S \text { and } \mathrm{Nz}-\mathrm{PML}\end{array}$} \\
\hline \multicolumn{2}{|c|}{ General characteristics, mean (SD) } & $\begin{array}{l}\text { Whole cohort } \\
(\mathrm{N}=23)\end{array}$ \\
\hline \multicolumn{2}{|c|}{ Age at MS onset, $y$} & $29.5(7.6)$ \\
\hline \multicolumn{2}{|c|}{ Female, \% (n) } & $65.2(15)$ \\
\hline \multicolumn{2}{|c|}{ Age at PML onset, y } & $41.3(7.8)$ \\
\hline \multicolumn{2}{|c|}{ Duration of MS before Nz onset, y } & $12.0(5.3)$ \\
\hline \multicolumn{2}{|c|}{ No. of MS therapies before $\mathrm{Nz}$ onset } & $2.48(1.38)$ \\
\hline \multicolumn{3}{|c|}{$\mathrm{Nz}$ treatment } \\
\hline \multicolumn{2}{|c|}{ EDSS at Nz onset } & $4.32(1.69)$ \\
\hline \multicolumn{2}{|c|}{ EDSS after 1 y of $\mathrm{Nz}$ therapy } & $4.15(1.68)$ \\
\hline \multicolumn{2}{|c|}{ No. of $\mathrm{Nz}$ infusions } & $45.9(14.7)$ \\
\hline \multicolumn{2}{|c|}{ Duration of $\mathrm{Nz}$ therapy, $\mathrm{y}$} & $3.86(1.58)$ \\
\hline \multicolumn{3}{|c|}{$\begin{array}{l}\text { No. of relapses during } \mathrm{Nz} \text { therapy, } \\
\%(\mathrm{n})\end{array}$} \\
\hline \multicolumn{2}{|l|}{0} & $60.9(14)$ \\
\hline \multicolumn{2}{|l|}{1} & $26.1(6)$ \\
\hline \multicolumn{2}{|l|}{$\geq 2$} & 13.0 (3) \\
\hline \multicolumn{3}{|c|}{ PML, \% (n) } \\
\hline \multicolumn{3}{|c|}{ Symptoms } \\
\hline \multicolumn{2}{|c|}{ Limb weakness } & $43.5(10)$ \\
\hline \multicolumn{2}{|c|}{ Cerebellar syndrome } & $30.4(7)$ \\
\hline \multicolumn{2}{|c|}{ Speech disorders } & $17.4(4)$ \\
\hline \multicolumn{2}{|c|}{ Cognitive disorders } & $21.7(5)$ \\
\hline \multicolumn{2}{|c|}{ Visual field defects } & $17.4(4)$ \\
\hline \multicolumn{2}{|c|}{ Asymptomatic } & $8.70(2)$ \\
\hline \multicolumn{2}{|c|}{ Other symptoms } & $26.1(6)$ \\
\hline \multicolumn{3}{|c|}{ Localization } \\
\hline Fron & & $36.4(8)$ \\
\hline Occi & & $9.09(2)$ \\
\hline Parie & & $13.6(3)$ \\
\hline Brair & & 9.09 (2) \\
\hline Mult & & $31.8(7)$ \\
\hline Gadoli & enhancement & $54.5(12)$ \\
\hline Post-Nz & tments & \\
\hline $\begin{array}{l}\text { Follow } \\
\text { Nz-PM }\end{array}$ & $\begin{array}{l}\text { duration after } \\
10\end{array}$ & $24.3(10.7)$ \\
\hline No. of & therapies after $\mathrm{Nz}-\mathrm{PML}$ & $1.35(0.57)$ \\
\hline $\begin{array}{l}\text { Durati } \\
\text { treatm }\end{array}$ & $\begin{array}{l}\text { f each MS } \\
\text { mo }\end{array}$ & \\
\hline Glati & er acetate $(n=11)$ & $15.7(9.4)$ \\
\hline DMF & $=5)$ & 3.35 (1.75) \\
\hline $\mathrm{Fg}(\mathrm{n}$ & & $13.9(10.2)$ \\
\hline Inter & on $\beta 1 \mathrm{a}(\mathrm{n}=4)$ & $9.91(6.63)$ \\
\hline Inter & on $\beta$ 1b ( $n=3)$ & $11.0(3.5)$ \\
\hline $\begin{array}{l}\text { EDSS } \\
\text { MS DN }\end{array}$ & tart of the first rescue & $5.38(1.82)$ \\
\hline
\end{tabular}

Continued

\section{Table 1 Continued}

$\begin{array}{ll}\text { General characteristics, mean (SD) } & \begin{array}{l}\text { Whole cohort } \\ (\mathbf{N}=23)\end{array} \\ \text { EDSS at last follow-up } & 5.20(1.89) \\ \text { EDSS change } & -0.200(0.594)\end{array}$

Abbreviations: DMF = dimethyl fumarate; DMT = diseasemodifying therapy; EDSS = Expanded Disability Status Scale; EDSS change $=$ difference of EDSS at the end of the followup and EDSS at the start of the first subsequent MS DMT; $\mathrm{Fg}$ = fingolimod; $\mathrm{MS}=$ multiple sclerosis; Nz-PML, natalizumab-related progressive multifocal leukoencephalopathy.

METHODS Eleven MS tertiary care centers, 10 in France and 1 in Belgium, collected data. All included patients fulfilled the following criteria: (1) RR-MS; (2) Nz-PML confirmed by detection of JC virus DNA in the CSF by PCR; (3) Nz-PML survivors, i.e., still alive after PML diagnosis and immune reconstitution inflammatory syndrome (IRIS); and (4) post-PML initiation of DMT. Patients who died before receiving DMT were then excluded.

We describe the clinical and radiologic evolution after Nz-PML and IRIS including (1) disability progression-assessed by Expanded Disability Status Scale (EDSS) change between DMT initiation after PML and the end of follow-up, (2) disease activityassessed clinically by annual relapse rate (ARR) and radiologically by the appearance of new T2 MS lesions or new gadoliniumenhanced T1 lesions on MRI over the period of follow-up, and (3) modification of PML lesions on MRI.

Data collection. Data were anonymously collected through a questionnaire (sent in September 2014), which was completed by local neurologists. Data collection was stopped in February 2015.

For each patient, we collected demographic data including age, sex, and clinical characteristics: age at disease onset; MS treatments before $\mathrm{Nz}$ with duration, efficacy and side effects; treatment by $\mathrm{Nz}$ with number of infusions, EDSS at onset, and after 1 year of Nz; clinical and radiologic description of PML; EDSS and MRI at PML onset and at onset of post-PML DMT; description of post-PML DMT with duration, efficacy and side effects, and delay of switch; EDSS and MRI at the end of the follow-up.

The number of different post-PML MS treatments, the median, and the mean duration of each post-PML DMT were calculated. The ARR, defined as the number of relapses during the treatment period divided by the duration of the treatment, was calculated for each treatment. EDSS change was assessed from the onset of post-PML DMT and the end of the followup. All patients underwent an MRI at the onset of post-PML DMT and a second one at the end of the follow-up: the change in number and size of the lesions between PML diagnosis and post-PML DMT was visually assessed and classified as increased, decreased, or stable. Gadolinium enhancement was also reported.

Standard protocol approvals, registrations, and patient consents. All patients gave oral informed consent to be included in the European Database for Multiple Sclerosis (EDMUS); therefore, no additional consent or institutional review board approval was sought. All anonymous data were gathered in the Pitié-Salpêtrière tertiary care center in Paris.

Statistical analysis. General characteristics of the whole sample were analyzed using percentage and number for categorical variables and using mean and SD for numerical variables.

SAMPLE ANALYSIS Clinical and demographic characteristics of the 23 included patients are summarized 
Figure 1 Timeline of subsequent MS treatments, after Nz-PML for each patient of the cohort

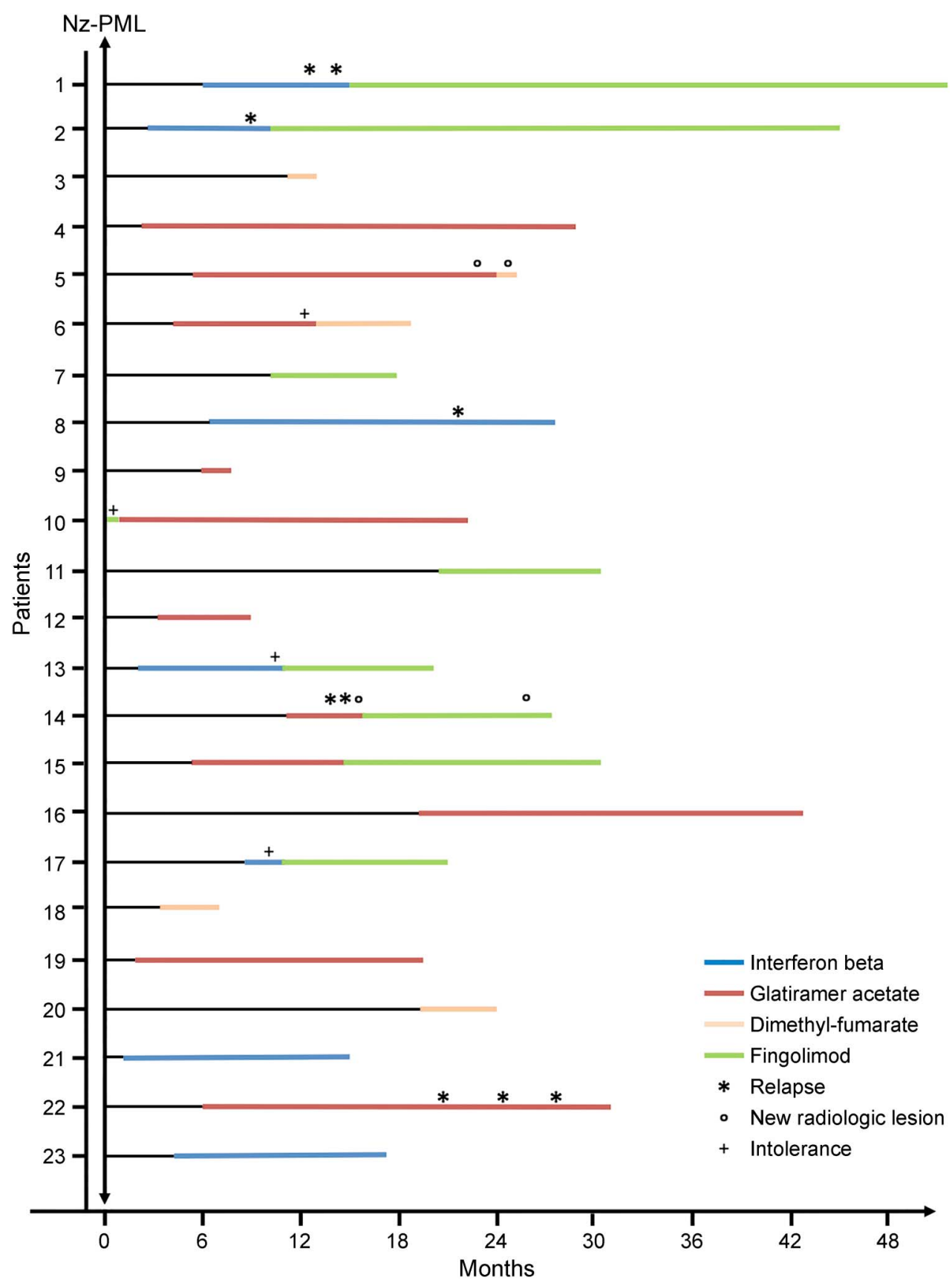

The zero on the $\mathrm{x}$-axis represents the diagnosis of Nz-PML. Black line: washout period after natalizumab cessation without any MS disease-modifying therapy. Blue line: interferon $\beta$. Red line: glatiramer acetate. Peach line: dimethyl fumarate. Green line: fingolimod. Asterisk: one clinical relapse. Circle: new MS lesions on brain MRI. Cross: intolerance of the treatment. MS = multiple sclerosis; $\mathrm{Nz}-\mathrm{PML}$ = natalizumab-related progressive multifocal leukoencephalopathy. Adapted from reference 6, with permission; @ 2014 SAGE Publications.

in table 1 and table e-1 at Neurology.org/nn (results with median and interquartile range). The mean age was $29.5(\mathrm{SD}=7.6)$ years, and $65 \%(\mathrm{~N}=15)$ of patients were women. The mean disease duration before $\mathrm{Nz}$ was 12.0 years (5.3), and EDSS at $\mathrm{Nz}$ onset was 4.32 (1.68).

PML occurred on average after 45.9 (14.7) infusions, i.e., 3.86 years (1.58). The most frequent initial PML symptoms were limb weakness (43.5\%) and cerebellar ataxia (30.4\%). MRI revealed a unique frontal lesion in $36.4 \%$ of cases. Multifocal lesions were observed in $31.8 \%$ of cases, and gadolinium enhancement was detected in $54.5 \%$ of cases at Nz-PML diagnosis. Brain MRI of patient 1 is shown as example in figure e-1.

After PML, the mean follow-up was 24.1 (10.8) months. Post-PML MS DMT was initiated on 


\begin{tabular}{|c|c|c|c|c|c|c|c|c|c|c|}
\hline \multicolumn{11}{|c|}{ Table 2 Post-PML MS DMTs } \\
\hline \multirow[b]{2}{*}{$\begin{array}{l}\text { Post-PML MS DMT, } \\
\text { mean (SD) }\end{array}$} & \multicolumn{5}{|c|}{ First post-PML MS treatment } & \multicolumn{5}{|c|}{ Second post-PML MS treatment } \\
\hline & $\mathrm{n}$ & $\begin{array}{l}\text { First switch } \\
\text { delay, mo }\end{array}$ & Duration, mo & ARR & EDSS change & $\mathbf{n}$ & $\begin{array}{l}\text { Second switch } \\
\text { delay, mo }\end{array}$ & Duration, mo & ARR & EDSS change \\
\hline Glatiramer acetate & 10 & $7.31(5.65)$ & $15.3(9.7)$ & $0.73(1.53)$ & 0 (0.62) & 1 & 6.47 & 20.9 & 0 & -0.5 \\
\hline DMF & 3 & $11.6(7.7)$ & $3.76(1.10)$ & $0(0)$ & $-0.50(0.707)$ & 2 & $20.3(11.4)$ & $2.76(2.98)$ & $0(0)$ & $0(0)$ \\
\hline $\mathrm{Fg}$ & 3 & $10.4(8.8)$ & $5.51(4.73)$ & $0(0)$ & $-0.25(0.356)$ & 6 & $16.0(5.2)$ & $18.4(9.8)$ & $0(0)$ & $-0.25(1.129)$ \\
\hline IFN $\beta$ 1A & 4 & $5.68(2.90)$ & $9.91(6.63)$ & $0.595(0.810)$ & $0(0)$ & 0 & & & & \\
\hline IFN $\beta$ 1B & 3 & $2.90(1.89)$ & $11.0(9.0)$ & $0.89(1.534)$ & $0(0)$ & 0 & & & & \\
\hline
\end{tabular}

Abbreviations: ARR = annual relapse rate; DMF = dimethyl fumarate; DMT = disease-modifying therapy; EDSS = Expanded Disability Status Scale; Fg = fingolimod; IFN = interferon; MS = multiple sclerosis; PML = progressive multifocal leukoencephalopathy; switch delay = delay between natalizumab cessation and other MS DMT onset.

average 7.43 (5.83) months after $\mathrm{Nz}$ treatment withdrawal. Post-PML MS treatments are detailed for each patient in a timeline (figure 1). The mean duration for each treatment is summarized in table 2 .

With regard to disability progression, there was no clinical worsening of PML symptoms as assessed by stability of EDSS at the last follow-up (EDSS change -0.2 , table 1 ); no patient died later during the follow-up.

ARRs during each post-PML therapy are shown in table 2: no relapse was reported with Fg and DMF. Three patients on glatiramer acetate given as the first treatment exhibited sustained MS radiologic activity after 18 months (6-30). In one patient, this activity persisted also 12 months after the switch to Fg. Concerning $\mathrm{Nz}-\mathrm{PML}$ lesions, no radiologic worsening was observed at the end of the follow-up period. The size of PML lesions was estimated as stable in 10 cases and decreased in 13 cases. No gadolinium enhancement was noticed (figure e-1).

Among the 9 patients with more than 6 months Fg or DMF treatment, the mean lymphocyte count was $595 / \mathrm{mm}^{3}(294-1,450)$, with 4 patients with prolonged lymphopenia for more than 6 months $\left(<500 / \mathrm{mm}^{3}\right)$.

DISCUSSION The choice of post-PML MS treatment after Nz-PML is challenging and remains a matter of debate. In this largest cohort of Nz-PML survivors to date, no clinical or radiologic PML worsening was observed with any of the reported post-PML DMT, especially with DMF and Fg.

However, this reassuring evolution has to be interpreted with caution because of the low number of patients treated with Fg and DMF on the one hand and the short duration of both treatments, particularly DMF (3.35 months) because of recent DMF availability in France, on the other hand. Indeed, in the 4 DMF-PML cases recently reported, ${ }^{4}$ PML started 18 months or more after DMF onset, with a lymphocyte count below
$500 / \mathrm{mm}^{3}$ during more than 12 months for 3 of them. In addition, in the 5 cases of Fg-PML, ${ }^{5}$ the minimal time of Fg exposure before PML onset was 30 months with a lymphocyte count below $500 / \mathrm{mm}^{3}$ for 2 of them. In our cohort, the mean duration of $\mathrm{Fg}$ treatment (corresponding to 9 patients) was 14.4 months. ${ }^{6}$

In this cohort, the high number (mean 2.48; SD 1.38) of MS therapy used before $\mathrm{Nz}$ onset reflected the high level of MS activity. It is likely that the optimal post-PML DMT choice should differ depending on pre-Nz severity/activity of the disease. Indeed, in patients with highly active MS, the reappearance of disease activity after $\mathrm{Nz}$ discontinuation seems faster and more severe than in patients with low activity preceding $\mathrm{Nz}$ treatment. ${ }^{8}$ Fg prevents relapses in active MS and is considered as more efficient than interferon $\beta .{ }^{9}$ This may explain the high number of patients treated with $\mathrm{Fg}$ in our cohort. The mean delay of Nz-Fg switch (mean 10.4 months [8.8]) was longer than recommended in a recent collaborative French study. ${ }^{10}$ In this situation, regardless of the delay, patients remain relapse free over the follow-up.

The main limitation of this work is its retrospective and multicenter design. Because brain MRI was performed in different centers, data were analyzed in each tertiary center by a neuroradiologist and a treating neurologist with qualitative visual qualification. A new prospective centralized quantitative assessment of PML lesions volume, T2 MS lesion load, and brain atrophy should be performed to confirm this analysis.

With 685 cases worldwide in September 2016, $\mathrm{Nz}-\mathrm{PML}$ is a challenge in our current medical practice. The description of the largest cohort of $\mathrm{Nz}$ PML patients to date suggests that MS therapies given after $\mathrm{Nz}$ discontinuation in patients with PML were not associated with PML worsening. A larger cohort with a longer follow-up will be necessary to confirm this therapeutic strategy. 


\section{AUTHOR CONTRIBUTIONS}

Elisabeth Maillart has contributed to the study concept and design, analysis and interpretation of the data, and drafting and revising of the manuscript for content. Jean-Sebastien Vidal has contributed to the study concept and design, analysis and interpretation of the data, statistical analysis, and revising of the manuscript for content. David Brassat, Bruno Stankoff, Agnès Fromont, Jérôme de Sèze, Frédéric Taithe, Pierre Clavelou, Bertrand Bourre, Valérie Delvaux, Audrey Rico, Pierre Labauge, Ayman Tourbah, Christine Lebrun, Jean Pelletier, and Thibault Moreau have contributed to revising of the manuscript for content. Céline Louapre has contributed to the analysis and interpretation of the data and revising of the manuscript for content. Catherine Lubetzki has contributed to the analysis and interpretation of the data and drafting/revising of the manuscript for content. Caroline Papeix has contributed to the study concept and design, analysis and interpretation of the data, and drafting/revising of the manuscript for content.

\section{STUDY FUNDING}

No targeted funding reported.

\section{DISCLOSURE}

E. Maillart served on the scientific advisory board for Genzyme, Roche, Novartis, and Merck and received travel funding and/or speaker honoraria from Biogen, Teva Pharmaceuticals, Genzyme, Roche, Novartis, and Merck. J.-S. Vidal reports no disclosures. D. Brassat received travel funding and/or speaker honoraria from Biogen, Bayer, Novartis, Sanofi, Almirall, Merck, and Teva and received research support from FP7 and PHRC. B. Stankoff served on the scientific advisory board for Roche, Biogen, Novartis, and Sanofi; received travel funding and/or speaker honoraria from Biogen, Teva, Genzyme, and Novartis; and received research support from Merck Serono, Genzyme, Fondation ARSEP, and PMSA. A. Fromont reports no disclosures. J. de Sèze served on the editorial board for Revue Neurologique. F. Taithe received travel funding and/or speaker honoraria from Novartis, Teva, Biogen, and Genzyme. P. Clavelou served on the scientific advisory board for Novartis, Teva Pharmaceuticals, Bayer, Biogen, Genzyme-Sanofi, Almirall, and Roche; received travel funding and/or speaker honoraria directly to department of neurology from Novartis, Teva Pharmaceuticals, Biogen, Merck, Bayer, LFB, Genzyme-Sanofi, Actelion, and Roche; and served on the editorial board for La lettre du neurologue. B. Bourre served on the scientific advisory board for Biogen Idec, Novartis, Genzyme, Merck Serono, and Teva and received travel funding and/or speaker honoraria from Biogen Idec, Novartis, Genzyme, Merck Serono, and Teva. V. Delvauz served on the scientific advisory board for Novartis, Biogen, Sanofi, Merck, and Roche. A. Rico and P. Labauge report no disclosures. A. Tourbah served on the scientific advisory board for Medday Pharmaceuticals, Sanofi-Genzyme, Novartis, Merck Serono, and Teva Pharmaceuticals; received travel funding and/or speaker honoraria from Biogen Idec, Sanofi-Genzyme, Novartis, Merck Serono, and Teva Pharmaceuticals; has consulted for Medday and Teva Pharmaceuticals; served on the speakers' bureau for Biogen Idec, Sanofi-Genzyme, Novartis, Merck Serono, and Teva Pharmaceuticals; received research support from Medday Pharmaceuticals, Biogen Idec, Sanofi-Genzyme, Novartis, and Roche; consulted; and received lecturing fees, travel grants, or research support from Medday Pharmaceuticals, Biogen Idec, Sanofi-Genzyme, Novartis, Merck Serono, Teva Pharmaceuticals, and Roche. C. Lebrun served on the scientific advisory board for Biogen, Novartis, Merck, Genzyme, Teva, and Roche; received travel funding and/or speaker honoraria from Biogen, Merck, Genzyme, and Roche; served on the editorial board for Revue Neurologique (Paris) Elsevier and Neurology and Therapy; and received research support from UT Southwestern, French MS Society EDMUS Foundation. J. Pelletier served on the scientific advisory board for Biogen Idec, Novartis, and Genzyme and received research support from ARSEP. T. Moreau received consulting and speaking fees from Biogen Idec, Sanofi-Aventis, Genzyme, Teva Pharmaceuticals, Bayer Schering, Merck Serono, Roche, Almirall, Novartis, and Roche and is rédacteur en chef of La lettre du neurologue. C. Louapre served on the scientific advisory board for Genzyme and Merck Serono and received travel funding and/or speaker honoraria from Biogen Idec and Genzyme. C. Lubetzki served on the scientific advisory board for Vertex, Biogen, Novartis, Genzyme, Roche, and Vertex; is an associate editor for Brain; is on the editorial board for Multiple Sclerosis Journal and Multiple Sclerosis and Related Disorders; has consulted for Biogen, Roche, Genzyme, and Vertex; had scientific collaboration with EMD Serono; and received research support from EMD Serono, Vertex. C. Papeix received travel funding and/or speaker honoraria from Novartis, Biogen, Teva, Roche, Merck, and Biogen Idec. Go to Neurology.org/nn for full disclosure forms.

Received December 28, 2016. Accepted in final form March 3, 2017.

\section{REFERENCES}

1. Clifford DB, De Luca A, Simpson DM, Arendt G, Giovannoni G, Nath A. Natalizumab-associated progressive multifocal leukoencephalopathy in patients with multiple sclerosis: lessons from 28 cases. Lancet Neurol 2010;9: 438-446.

2. Baldwin KJ, Hogg JP. Progressive multifocal leukoencephalopathy in patients with multiple sclerosis. Curr Opin Neurol 2013;26:318-323.

3. Rosenkranz T, Novas M, Terborg C. PML in a patient with lymphocytopenia treated with dimethyl fumarate. $\mathrm{N}$ Engl J Med 2015;372:1476-1478.

4. Available at: fda.gov/Drugs/DrugSafety/ucm 424625.htm. First online: November 25, 2014, update January 16, 2016.

5. Available at: fda.gov/Drugs/DrugSafety/ucm456919.htm. First online: August 4, 2015, update January 15, 2016. Accessed January 252017.

6. Maillart E, Louapre C, Lubetzki C, Papeix C. Fingolimod to treat severe multiple sclerosis after natalizumabassociated progressive multifocal leukoencephalopathy: a valid option? Mult Scler 2014;20:505-509.

7. Hoepner R, Faissner S, Ellrichmann G, Schneider R, Gold R. Rituximab postprogressive multifocal leukoencephalopathy: a Feasible therapeutic option in selected cases. Ther Adv Neurol Disord 2014;7:289-291.

8. O'Connor PW, Goodman A, Kappos L, et al. Disease activity return during natalizumab treatment interruption in patients with multiple sclerosis. Neurology 2011;76: 1858-1865.

9. Cohen JA, Barkhof F, Comi G, et al. Oral fingolimod or intramuscular interferon for relapsing multiple sclerosis. $\mathrm{N}$ Engl J Med 2010;362:402-415.

10. Cohen M, Maillart E, Tourbah A, et al. Switching from natalizumab to fingolimod in multiple sclerosis: a French prospective study. JAMA Neurol 2014;71:436-441. 


\title{
Neurology $^{\odot}$ \\ Neuroimmunology \& Neuroinflammation
}

\author{
Natalizumab-PML survivors with subsequent MS treatment: Clinico-radiologic \\ outcome \\ Elisabeth Maillart, Jean-Sebastien Vidal, David Brassat, et al. \\ Neurol Neuroimmunol Neuroinflamm 2017;4; \\ DOI 10.1212/NXI.0000000000000346
}

This information is current as of April 14, 2017

Neurol Neuroimmunol Neuroinflamm is an official journal of the American Academy of Neurology.

Published since April 2014, it is an open-access, online-only, continuous publication journal. Copyright

Copyright (C) 2017 The Author(s). Published by Wolters Kluwer Health, Inc. on behalf of the American

Academy of Neurology. All rights reserved. Online ISSN: 2332-7812.

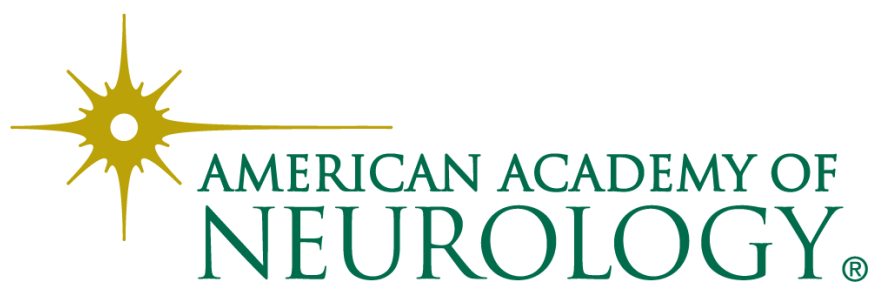




\section{Updated Information \& Services}

\section{Supplementary Material}

\section{References}

Citations

Subspecialty Collections

Permissions \& Licensing

\section{Reprints}

including high resolution figures, can be found at: http://nn.neurology.org/content/4/3/e346.full.html

Supplementary material can be found at: http://nn.neurology.org/content/suppl/2017/04/14/4.3.e346.DC1 http://nn.neurology.org/content/suppl/2017/04/14/4.3.e346.DC2

This article cites 8 articles, 0 of which you can access for free at: http://nn.neurology.org/content/4/3/e346.full.html\#\#ref-list-1

This article has been cited by 1 HighWire-hosted articles: http://nn.neurology.org/content/4/3/e346.full.html\#\#otherarticles

This article, along with others on similar topics, appears in the following collection(s):

\section{Multiple sclerosis}

http://nn.neurology.org//cgi/collection/multiple_sclerosis

\section{Viral infections}

http://nn.neurology.org//cgi/collection/viral_infections

Information about reproducing this article in parts (figures,tables) or in its entirety can be found online at:

http://nn.neurology.org/misc/about.xhtml\#permissions

Information about ordering reprints can be found online: http://nn.neurology.org/misc/addir.xhtml\#reprintsus

Neurol Neuroimmunol Neuroinflamm is an official journal of the American Academy of Neurology.

Published since April 2014, it is an open-access, online-only, continuous publication journal. Copyright

Copyright $\odot 2017$ The Author(s). Published by Wolters Kluwer Health, Inc. on behalf of the American Academy of Neurology. All rights reserved. Online ISSN: 2332-7812.

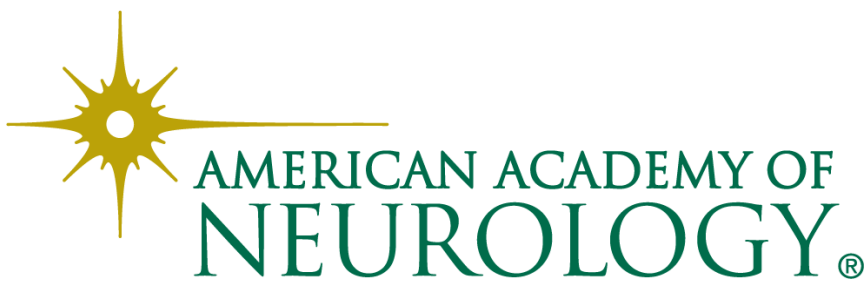

